\title{
An empirical analysis of the time allocation of Italian couples: are they responsive?
}

\author{
Hans G. Bloemen • Silvia Pasqua • \\ Elena G. F. Stancanelli
}

Received: 6 November 2008/Accepted: 16 November 2009/Published online: 13 December 2009

(C) The Author(s) 2009. This article is published with open access at Springerlink.com

\begin{abstract}
The literature suggests that in Italy husbands contribute less to unpaid household work than in any other European country, while women have the lowest market employment rates. Here we examine the time allocation of Italian couples on which there are surprisingly few studies to date. We analyze simultaneously the time allocated by husband and wife to market work, childcare and housework, allowing for various interactions. We use data drawn from the Italian national Time Use Survey 2002-2003 for the analysis. We find that spousal time allocation is sensitive to personal and household characteristics, such as, in particular, education and children's age. Evidence shows that men married to more highly educated women spend more time with their children. The husband's own characteristics have less of an effect on women's time allocation. We also find that patterns differ substantially between weekends and weekdays. The estimated correlations between the unobservable factors affecting the couple's time allocation suggest that the time devoted by parents to childcare is complementary and that the time they devote to housework is substitutable across weekends and other weekdays.
\end{abstract}

H. G. Bloemen

Tinbergen Institute, Free University of Amsterdam, Amsterdam, The Netherlands

H. G. Bloemen

Netspar and IZA, Bonn, Germany

S. Pasqua

University of Turin, Turin, Italy

S. Pasqua

CHILD-Collegio Carlo Alberto, Moncalieri, Italy

E. G. F. Stancanelli ( $₫)$

CNRS, THEMA, University of Cergy Pontoise, Cergy Pontoise, France

e-mail: elenastancanelli@free.fr 
Keywords Time allocation · Work behavior · Household economics

JEL Classifications $\quad$ D $1 \cdot$ D13 $\cdot$ J21

\section{Introduction}

International data indicate that Italian men carry out less unpaid household work than men in most other OECD countries, being second only to Japanese men (OECD 2001). Burda et al. (2006, 2007) conclude that men and women do the same amount of "total" work, defined as the sum of market and non-market work, in all European countries except Italy, where men are shown to work substantially less than women. In Table 1, we show the average time allocated to different activities by men and women in a number of European countries, according to the Harmonized European Time Use Survey (HETUS). ${ }^{1}$ Italian men are indeed found to perform the least domestic work among men in the countries considered, second to Spaniards. As for Italian women, they stand out as the least active in the labor market, followed closely only by Belgian and German women.

There are surprisingly few studies of the time allocation of Italian couples. Mencarini and Tanturri (2004) analyzed the time allocation of Italian spouses in conjunction with the arrival of a new-born child, in different types of households, using data from a time use survey carried out in five large towns located in the North, the Centre and the South of Italy (Florence, Messina, Padua, Pesaro and Udine). The authors conclude that the market time of men increased following the birth of a child while their childcare time was almost unaffected. Anxo et al. (2007) carried out a comparative analysis of how individuals allocate their time to market work, non-market work (including childcare) and leisure over their life cycle in a number of countries, including Italy. In particular, they find that Italian women tend to specialize in household production more than women in other countries and that the time they allocate to housework increases dramatically with the birth of a new child and the presence of small children.

In this paper, we study how Italian spouses allocate time between market work and non-market time, distinguishing between three time uses: paid work, childcare and housework. To our knowledge, this is one of the first papers to simultaneously analyze the time use decisions of partners within the same household. The New home economics' (see Mincer (1962) for initial developments in this area, and Apps and Rees (2009) for a review of the international literature, both theoretical and empirical) recognized the importance of the structure of the household in the decisions of household members, and emphasizes that spouses' decisions are taken simultaneously. Further developments in this area include Grossbard-Schechtman (1984), addressing time allocation decisions within households, incorporating the

\footnotetext{
1 The table is taken from the online information on HETUS provided at https://www.testh2.scb.se/ tus/tus/. Each national statistical institute is responsible for the accuracy of data they have contributed to the database. Statistics Finland is responsible for setting up and harmonizing the database. Statistics Sweden has built and runs the table generating tool. The contributing National Statistical Institutes have approved the technique by which the estimates are calculated by the tool.
} 
Table 1 Paid work, domestic work and leisure of Europeans

\begin{tabular}{|c|c|c|c|c|c|c|}
\hline & $\begin{array}{l}\text { Paid work } \\
\text { men }\end{array}$ & $\begin{array}{l}\text { Domestic } \\
\text { work men }\end{array}$ & $\begin{array}{l}\text { Leisure } \\
\text { time men }\end{array}$ & $\begin{array}{l}\text { Paid work } \\
\text { women }\end{array}$ & $\begin{array}{l}\text { Domestic work } \\
\text { women }\end{array}$ & $\begin{array}{l}\text { Leisure time } \\
\text { women }\end{array}$ \\
\hline \multicolumn{7}{|c|}{ Mean minutes per day-activity } \\
\hline Belgium & 187 & 148 & 358 & 113 & 250 & 306 \\
\hline Bulgaria & 212 & 157 & 286 & 154 & 301 & 227 \\
\hline Estonia & 267 & 153 & 302 & 185 & 293 & 258 \\
\hline Finland & 228 & 136 & 356 & 153 & 236 & 317 \\
\hline France & 228 & 144 & 284 & 137 & 274 & 245 \\
\hline Germany & 207 & 142 & 342 & 116 & 254 & 315 \\
\hline Italy & 255 & 95 & 305 & 112 & 320 & 246 \\
\hline Latvia & 300 & 110 & 285 & 209 & 236 & 248 \\
\hline Lithuania & 285 & 129 & 287 & 211 & 269 & 225 \\
\hline Norway & 244 & 141 & 352 & 158 & 227 & 340 \\
\hline Poland & 241 & 142 & 320 & 135 & 285 & 272 \\
\hline Slovenia & 233 & 158 & 331 & 162 & 296 & 267 \\
\hline Spain & 261 & 97 & 316 & 126 & 295 & 266 \\
\hline Sweden & 251 & 149 & 318 & 174 & 222 & 297 \\
\hline United Kingdom & 250 & 138 & 322 & 144 & 255 & 295 \\
\hline
\end{tabular}

Source Harmonized European Time Use survey (HETUS): individuals aged 20-74 years. The years covered vary country by country. Domestic work includes childcare time and excludes travelling time. Paid work excludes travel time to work. The Italian data are drawn from the same time use survey that we use for the analysis in this paper

role of household structure and marriage, while allowing household members to have their own individual preferences. ${ }^{2}$ In this paper the interactions between spousal decisions will be incorporated in estimating the time allocation model. Bloemen and Stancanelli (2008) applied the same approach to France using a more sophisticated model - which was possible because of the more complete French dataset. Connelly and Kimmel (2009) investigated spousal leisure, home production and childcare and the impact of wages. Here, we also make an attempt to estimate the impact of individual and cross (partner's) wage on the time allocation decision ${ }^{3}$ by bringing in wage information-which is missing in the Italian time use datafrom a different dataset.

Many studies in the literature only focus on one time use at a time, but there are notable exceptions starting from the pioneering work of Kooreman and Kapteyn (1987) that allow for greater disaggregation of domestic work into many non-market activities (see also Connelly and Kimmel 2009; Bloemen and Stancanelli 2008).

\footnotetext{
${ }^{2}$ McElroy and Horney (1981) and Manser and Brown (1980) added to this line of research by explicitly modeling bargaining processes between spouses.

${ }^{3}$ See, for example, Grossbard-Shechtman (2003) for a useful discussion of the effects of wages on spousal time allocation. Bloemen and Stancanelli (2008) model simultaneously wage rates, employment, and time allocation of French spouses within each household, distinguishing three main time uses: paid work, childcare and household chores.
} 
Of the three different time uses we analyze, childcare time and housework time are likely to be valued differently by individuals, and, thus, the estimated effects of covariates will differ. It is, therefore, important to disaggregate them.

Finally, we estimate the correlations across the unobservables of the partners' time use equations, which helps to shed light on the significance and the direction of the interactions between the two spouses (see Bloemen and Stancanelli 2008, for more details). For example, positive assortative mating ${ }^{4}$ may result in positive correlation of the unobservables affecting the time allocation decisions of the two spouses. Substitutability of one spouse's time for the other's in household production could lead to negative correlations. Negative or insignificant correlations might be explained in part by specialization of one spouse in housework and the other in market work.

For our empirical analysis we use data drawn from the Italian national Time Use Survey 2002-2003. All household respondents were asked to fill in a time-use diary. Diaries were collected for weekends and other weekdays: a third of the households were required to complete a diary on a Saturday, a third on a Sunday, and the remaining third on a weekday. On weekends most individuals are not engaged in formal work and thus may be able to dedicate more time to childcare and household chores. The impact of covariates may differ across weekdays and weekends. Therefore, we analyze separately spouses' time allocation on weekdays and on weekends. Because no information was collected on earnings or income, we draw some information on individual earnings from the 2002 Survey of Household Income and Wealth (SHIW) carried out by the Bank of Italy. This will be used for sensitivity analysis.

We conclude that partners' time allocation is sensitive to their own and household characteristics. In particular, education and children variables affect time allocation significantly. Men married to more highly educated women tend to spend more time caring for the children. The husband's characteristics have hardly any effect on the woman's time allocation, with the exception of a university degree, which significantly reduces the wife's market work on weekends and her household chores on weekdays. Residing in the North increases the amount of housework and childcare done by fathers and reduces the housework done by women, while it has no impact on childcare performed by women. We also find that patterns differ substantially across the week and the weekends. Finally, most estimated correlation coefficients are statistically significant, revealing patterns of positive assortative mating and complementarities between spouses' paid work and parental childcare activities. The errors between the equations for housework of the two parents are suggestive of complementarities between the husband's and wife's time inputs into the household production on weekends, but substitutability shows up on the other days of the week. The unobservable factors determining the time devoted to childcare and household chores time by one spouse are positively correlated with those of paid work of the other spouse, indicating specialization.

\footnotetext{
4 Positive assortative mating is usually defined as the positive correlation between partners' education and socio-economic background. This may also result in similar preferences for market work and household production.
} 
The structure of the paper is as follows. In Sect. 2 the econometric model is presented, while in Sect. 3 the data and sample selection criteria are illustrated. In Sect. 4 descriptive analysis is presented and the results of estimation of the model are discussed in Sect. 5. Conclusions follow.

\section{The empirical model}

The theoretical framework for our empirical specification is set up by the pioneering work of Becker (1965) and Gronau (1977) that allows for a trade-off between domestic work, market work and leisure. More recently, Apps and Rees (1997, 2002) develop a household model that incorporates household production and childcare time while Chiappori (1997) allows for home production in the collective model of household behavior.

We adopt the usual assumption that spouses in each household maximize household welfare subject to a budget constraint and a time constraint. Individuals consume goods and services bought from the market. Housework services and childcare services can also be produced by the household members. Utility is derived from total consumption (not observed in the data), leisure time and the time allocated to children and housework. Household welfare is a function of the individual utility functions of the husband and wife. The budget constraint is a function of the wage rates of the two spouses (not observed in the data), the time allocated to market work by each spouse and the total household non-labor income (which we do not observe in the data). The time constraint is equal to $24 \mathrm{~h}$ a day and it constrains the paid and unpaid activities performed by each spouse-here, paid work, housework, childcare and the remainder, which includes personal care time and sleeping time, together with leisure activities. Given that we do not observe the prices of substitutes for home production or the income of the household members, our approach is a reduced form model.

Here, we model simultaneously three different time uses-paid work, childcare and household work-for the two spouses within each household. To this end, activities performed by the two spouses are aggregated into three broad categories, following the usual practice (see Sect. 3). The remainder includes personal care time and sleeping time, together with leisure activities.

Let us denote with $t_{i j k}$, the time spent on activity $j$, with $j=1,2,3$ (time with children, time at work, and time for household work, respectively) by household member $k$, with $k=\mathrm{m}, f$ (where $\mathrm{m}$ is male and $\mathrm{f}$ is female), in household $i$, with $i=1, \ldots, N$. We model the time uses as a function of observed spouse characteristics, $x_{i k}, k=\mathrm{m}, \mathrm{f}$, household characteristics $x_{i h}$, and $\varepsilon_{i j k}$, unobservables. ${ }^{5}$ The empirical time allocation model is thus the following:

\footnotetext{
5 Note that the unobservable $\varepsilon$ captures both household and individual specific unobservable effects. Household and individual specific unobservable effects cannot be identified separately; this would require observing the same individual in different households, which contradicts the nature of the problem being studied. However, allowing for correlation between all errors of the equation system (4) is consistent with the possibility that the errors also include household specific unobservable effects.
} 
$t_{i j k}^{*}=x_{i \mathrm{~m}}^{\prime} \beta_{j k, \mathrm{~m}}+x_{i \mathrm{f}}^{\prime} \beta_{j k, \mathrm{f}}+x_{i h}^{\prime} \beta_{j k, h}+\varepsilon_{i j k} \quad j=1,2,3, \quad k=\mathrm{m}, \mathrm{f} \quad$ and $\quad i=1, \ldots, N$

$t_{i j k}=t_{i j k}^{*} \quad$ if $\quad t_{i j k}^{*}>0$

$t_{i j k}=0 \quad$ otherwise

In particular, we assume that one's own and one's spouse's age and education, in addition to the number and age of one's children, affect the time allocation decision of each spouse. Education is generally expected to have a positive effect on market work and childcare. The effect on housework is ambiguous, as more education may proxy higher income and thus more scope for buying household services from the market. On the other hand, if home productivity and market productivity were positively related, education could also have a positive impact on home production-under the assumption that individuals who are more productive in any given activity would allocate more time to it. In addition, we control for residence in the Northern part of Italy. ${ }^{6}$

We also try a specification where we include (predicted) wages, $\hat{w}_{i \mathrm{~m}}$ and $\hat{w}_{i \mathrm{f}}$, in $x_{i \mathrm{~m}}$ and $x_{i \mathrm{f}}$, to affect the spousal time allocation. ${ }^{7}$ The impact of wages on individual time choices is ambiguous in a model that allows for household production, as wages may have both an income effect and a substitution effect (for a discussion see Grossbard-Shechtman 2003; Bloemen and Stancanelli 2008). To single out the effect of covariates on choices, we only include couples with children in the sample.

This system of equations allows for zero time to be spent on a given activity (corner solution). Spending no time on a given activity may be either the result of choice or may be due to random sampling of the day the diary was filled in, so that on that particular day, that given activity was not performed.

We allow the errors of the six time use equations (three for each spouse) to be correlated with each other to allow for the simultaneity of spouses' time-allocation choices. To this end, we define:

$$
\omega_{i}=\left(\varepsilon_{i \mathrm{~m}}^{\prime} \quad \varepsilon_{i \mathrm{f}}^{\prime}\right)^{\prime} \quad \text { with } \quad \omega_{i} \sim N(0, \Sigma)
$$

where $\Sigma$ is the unrestricted variance-covariance 6 by 6 matrix of the errors of the six equations system.

\footnotetext{
6 This variable may capture institutional factors like the availability of part-time jobs and childcare facilities, which have been shown to affect women's employment participation decisions (Del Boca and Wetzels 2007; Del Boca et al. 2007, 2009), together with (possibly, their impact on) gender wage differentials, outside and within the household (Olivetti and Petrongolo 2008; Song 2007; Jepsen 2005).

7 The survey collects no information on earnings or income. Therefore, we draw information on individual earnings from the 2002 Survey of Household Income and Wealth (SHIW) carried out by the Bank of Italy. Using these data, we estimated a (log-)wage equation simultaneously with an employment equation by maximum likelihood, assuming that the errors followed a multivariate normal distribution. Thus, the estimates of the wage equation were corrected for selectivity. To predict wages for individuals in the Italian Time Use Survey, we used the values of the covariates in the time use survey and the coefficients of the wage equation from the Bank of Italy model, correcting for prediction error as customary. The standard errors of the time allocation model where the one's own and the one's spouse's predicted wage are included among the regressors are corrected as explained later.
} 
According to the theory, spouses' decisions are taken simultaneously. Estimating the correlations between the unobservables of the spousal equations helps shed light on the significance and the direction of the interactions between the two spouses. Correlations between the errors of the six time-use equations may arise from unobserved couple-specific correlations in preferences (for example, unobserved positive assortative mating or specialization effects), from unobserved productivity effects (someone who is productive in the labor market may also be productive in housework, or the opposite, if labor market attachment prevents individuals from accumulating housework experience) or from household-specific heterogeneity in market prices for housework and child care services-since we do not observe these variables.

To sum up, the complete model consists of the six time-use equations in Eq. 1 and the joint density of the errors in Eq. 2. We then construct the likelihood contribution for each type of observation. To deal with the multidimensionality of the model, we employ simulated maximum-likelihood estimation, using the GHK algorithm (see, for instance, Börsch-Supan and Hajivassiliou 1993). ${ }^{8}$ For the estimation of the model variants with predicted wages, standard errors are corrected for the use of parameter estimates of the wage regression in the prediction of wages. Since the asymptotic distributions of first (wages) and second stage (time use equations) estimators are known ${ }^{9}$ we derive a correction term for the standard errors.

We estimate the model separately for weekdays and weekend diaries. On weekends most individuals are not engaged in formal work and are therefore able to dedicate more time to childcare and household chores. They may also choose to perform fewer chores on weekends and enjoy more leisure time. Therefore, we allow the impact of covariates to differ across weekdays and weekends. This is all the more justified as the data are such that weekend diaries are oversampled, which implies that when covariates have different signs on weekends and weekdays, the weekend effect is likely to dominate and drive the estimates. For sensitivity purposes we also use a specification that pools together respondents observed during the week or on weekends, including a dummy variable for weekend diaries.

\footnotetext{
${ }^{8}$ We use 60 replications in the simulation of the likelihood function.

${ }^{9}$ The asymptotic distributions of first (wages) and second stage (time use equations) estimators are known under the usual regularity conditions for maximum likelihood (e.g. Amemiya 1985). Let $\theta$ denote the parameter vector containing all the parameters of the second stage estimation (the time use equation parameters, variances, and correlation coefficients of the errors) and let $\eta$ denote the parameters of the first stage (the wage distribution). Let $s(\theta ; \eta)$ denote the score (column) vector of the maximum likelihood estimation in the second stage. Let the estimator of the covariance of the parameter estimators of the first stage be denoted by $\Omega$. Then the correction term for the standard errors is
}

$$
\left[-\frac{\partial s(\hat{\theta} ; \hat{\eta})}{\partial \theta^{\prime}}\right]^{-1} \frac{\partial s(\hat{\theta} ; \hat{\eta})}{\partial \eta^{\prime}} \hat{\Omega} \frac{\partial s(\hat{\theta} ; \hat{\eta})^{\prime}}{\partial \eta}\left[-\frac{\partial s(\hat{\theta} ; \hat{\eta})^{\prime}}{\partial \theta}\right]^{-1}
$$

All factors in Eq. 3 can be estimated. The size of the correction factor depends on the size of the variance of the wage estimates, and on the degree to which the wage parameters influence the score vector of the time use equations. 


\section{The data}

We investigate the time allocation of Italian couples using data drawn from the national Time Use Survey 2002-2003, "Indagine Multiscopo sulle Famiglie-Uso del Tempo", carried out by the Italian National Statistical Office (ISTAT). The dataset covers 21,075 households, corresponding to 55,773 individuals, including children and other adults living in the household. An individual questionnaire containing socio-demographic information and a time-use diary were collected. In each municipality covered by the survey, households are assigned to one of three groups and each group was asked to fill in the daily diary at a different time: the first group on a weekday, the second group on a Saturday, and the third group on a Sunday. The over sampling of weekend diaries was a deliberate choice of the data collector (ISTAT).

This dataset is a representative survey of the Italian population. All household members were required to fill in a time diary.

The main disadvantage of this dataset is that no information was collected on earnings or income. Therefore, we have drawn information on individual earnings from the 2002 Bank of Italy Survey on Household Income and Wealth (SHIW) to predict and impute wages for the individuals in our time-use survey sample (see Sect. 3.3).

\subsection{Sample selection}

For the empirical analysis, we selected individuals according to the following criteria. They:

- were married ${ }^{10}$ and both spouses had filled in the diary. ${ }^{11}$ These first criteria reduced the original sample from the 21,075 households to 13,115 ;

- were between the ages of 18 and 60 at the time of the interview-this further shrank the sample size to 8,978 households;

- had at least one child younger than 19. ${ }^{12}$ By applying this criterion 3,483 households were eliminated;

- were not self-employed (1,863 couples excluded);

- were not in full-time education, retired, disabled, or in the military serviceeliminating 259 households;

- did not complete the diary on a "special" day (i.e. a vacation day or a sick day)_eliminating another 540 households.

The final sample for analysis thus consisted of 2,833 couple households: 1,784 of them filled in the diary on a weekend day and 1,049 couples answered the diary on a weekday.

\footnotetext{
${ }^{10}$ We did not select cohabitant couples, as there were simply too few. For the final sample that answered the diary at weekdays, there were only 33 unmarried couples.

11 The diary response rate was very high, as most adults surveyed filled in the diary.

12 Childless couples were dropped because including their corner solutions (no time spent with children on the day of the diary) would be difficult to interpret.
} 


\subsection{Time use variables and explanatory factors}

The diary collects information on the time spent on a large number of tasks. Activities can be performed simultaneously and are coded by the respondents as primary or secondary according to their own criteria. Here we only analyze those activities coded as primary to satisfy the time constraint (see Sect. 2). We distinguish between the following main activities:

- labor market work, excluding commuting time

- childcare, which includes feeding, bathing, dressing, helping them with homework, playing with them and taking them to school and extracurricular activities $^{13}$

- household chores, defined as cleaning the house, shopping, cooking, setting and unsetting the table, doing the laundry and the washing up, and paying bills.

This aggregation is customary (see Bloemen and Stancanelli 2008, for a discussion of aggregation bias).

As far as education goes, we use 'compulsory' ${ }^{14}$ education level, equivalent to 8 years of schooling, as the reference group. A separate dummy variable captures the impact of lower than 'compulsory' education (primary education or less). More than compulsory education is captured, respectively, by a secondary education dummy (2-5 years of secondary schooling) and a university degree, including both short degrees ( 2 years) and standard university degrees ( 4 or more years).

Next, we constructed a series of binary variables for the age of the youngest child in the household. We distinguish between two categories: the youngest child is younger than 3 years or from 3 to 5 . A dummy variable "North" (discussed before) captures the effect of living in the northern part of Italy although this does not necessarily reflect birthplace.

\subsection{Wage imputation}

As already mentioned, the Italian Time Use Survey does not contain any information on wages or income. To impute wages, we use the 2002 Bank of Italy Survey of Household Income and Wealth (SHIW), which is carried out every 2 years. The 2002 SHIW survey used here covers 8,011 households, and 22,148 individuals. The SHIW contains information on annual earnings (after taxes) and household non-labor income. Hours usually worked per week and months worked in the year are collected, and from this data we constructed hourly wages.

For the estimation of the wage regressions, we selected a sample that includes individuals aged 18-60 years, not retired, or self-employed or in full-time

\footnotetext{
13 See Kalenkoski and Foster (2008) for a useful discussion of the quality of primary and secondary childcare.

14 In Italy, students are required to complete 8 years of schooling. Those repeating a year or more, are still obliged to stay in full-time education until they complete this first cycle of education, or they are aged 15. For older cohorts, only primary schooling, consisting of 5 years, was compulsory.
} 
education. The resulting sample contains 4,853 women and 3,936 men. ${ }^{15}$ Among these observations, 2,412 women and 3,294 men were employed and reported their earnings and usual hours. ${ }^{16}$ The 2002 SHIW sample used for the wage regressions and the time-use sample are fairly comparable (see Table 12, in the "Appendix"), which is logical since they are both drawn from representative national surveys.

Using the SHIW sample, we estimated simultaneously a wage equation and an employment equation (by maximum likelihood, Heckman type of regression) to allow for selectivity. The regressors of the wage equation included education dummies, a quadratic expression in potential work experience ${ }^{17}$ and some measure of the unemployment rate. The employment equation also included a marital status dummy, a series of dummies for the age of the youngest child in the household ${ }^{18}$ and a control for the number of children. We also included the spouse's covariates and a dichotomous variable for the presence of other adults over 55 in the household, but they were not statistically significant at the ten per cent level. The estimation of the Heckman's regressions was carried out separately for men and women. ${ }^{19}$

We used the selectivity corrected parameter estimates of the wage equation to predict wages for individuals in the time use sample. Unfortunately, the sample does not provide many variables that can serve as exclusion restrictions: the variables that are included in the wage equation but not in the time use equations are the regional unemployment rate and potential work experience. Although potential work experience is constructed on the basis of age and education levels-variables that are included in the time use equations-it provides functional form identification. ${ }^{20}$ The regional unemployment rate turns out to be a significant predictor for the wages. Its use as an exclusion restriction is based on the argument that the time use equations are not directly affected by the unemployment rate- the unemployment rate may affect them indirectly though, through residence in the north. Because of the difficulty of finding more suitable identifying variables, we focus on the results of the model estimated without wages, and present the results of the model including predicted wages only as an additional sensitivity analysis.

\footnotetext{
15 The number 22,148 refers to all individuals in the sample including children and the elderly. The exclusions we made of individual under 18 years and over 60 (9,783 obs), retired (932), self employed $(1,536)$, full-time in education $(1,085)$, doing the military service (23) resulted in a sample of 8,789 individuals, made up of 4,853 women and 3,936 men.

${ }^{16}$ We also excluded individuals in the 1st, 2nd and 3rd and in the 97th, 98th and 99th percentile of the hourly wage distribution, to get rid of extreme values in the distribution of wages. In particular, some of these extreme values were so small or so high, that they might be misreported.

17 Potential experience was constructed, as usual, by subtracting schooling years from age, as the survey did not collect information on actual work experience. Work experience of women is bound to be overestimated because of higher inactivity and unemployment rates for women than men in Italy and possible career breaks related to childbearing.

${ }^{18}$ These dummy variables indicate if the youngest child is aged $0-2,3-5,6-13,14-18$.

19 Results are available upon request from the authors.

${ }^{20}$ Potential experience was set equal to age minus years of education, while age squared and education level dummies are entered in the time use equations. This provided only functional form identification because the underlying variables are the same in the two sets of equations (the wage equation and the time use equations) but they enter differently (the functional forms are different).
} 


\section{Descriptive analysis}

Descriptive statistics for the sample that answered the time-use diary during a weekday are given in Table 2. Summary statistics for the couples that filled in weekend diaries are shown in Table 9, in the "Appendix". They are fairly comparable samples. But the amount of time husbands allocate to household production and children is higher on weekends than on normal weekdays, whereas women tend to spend less time on childcare during the weekend.

In the sample of weekday diaries, the average age is 41 years for men and 38 years for women (see Table 2). Around $40 \%$ of the individuals of either gender have a compulsory education level (8 years of schooling), while $50 \%$ have completed secondary education. Less than $10 \%$ have a university degree and about the same proportion enjoys only primary education or less. The employment rate of married women is almost half that of married men: only $48 \%$ of the women in the sample work in the market, versus $96 \%$ of the men. The average number of children is 1.6 per couple. In $22 \%$ of the households the youngest child is below 3 years of age, while in $17 \%$ the youngest child is between 3 and 5 years. The table shows that married men devote to market work an average number of minutes that is almost three times that of married women: $420 \mathrm{~min}$ a day versus $146 \mathrm{~min}$ for women. In contrast, women devote on average, roughly, eight times more time to housework

Table 2 Sample descriptive statistics (weekdays)-Italian Time Use Survey, 2002-2003 (SD in brackets)

\begin{tabular}{lcc}
\hline & Husbands & Wives \\
\hline Age & $41.5(6.96)$ & $37.9(6.62)$ \\
Primary education & $0.08(0.28)$ & $0.08(0.27)$ \\
Compulsory education (reference) & $0.43(0.49)$ & $0.42(0.49)$ \\
Secondary education & $0.51(0.50)$ & $0.51(0.50)$ \\
University degree & $0.08(0.27)$ & $0.08(0.26)$ \\
Employed & $0.96(0.20)$ & $0.48(0.50)$ \\
Potential work experience & $25.13(7.70)$ & $21.54(7.34)$ \\
Hourly wage, Euros & $7.59(1.19)$ & $6.55(1.08)$ \\
Paid work time (minutes) & $422.4(187.9)$ & $145.7(197.7)$ \\
House work (minutes) & $40.7(60.6)$ & $320.9(151.0)$ \\
Childcare time (minutes) & $38.8(60.0)$ & $112.1(114.6)$ \\
\hline & Household characteristics & \\
\hline Children number & $1.61(0.68)$ & \\
Youngest child aged 0-2 & $0.22(0.42)$ & \\
Youngest child aged 3-5 & $0.17(0.38)$ & \\
North & $0.40(0.49)$ & \\
Regional unemployment rate & $10.3(7.27)$ & \\
N. obs. & 1,049 & \\
\hline
\end{tabular}

Note: see data section for more information on the variables in this table 
Table 3 Distribution of time allocation of husbands and wives (minutes)—married couples, weekdays (N. obs. 1049), percentiles

\begin{tabular}{llllll}
\hline & $10 \%$ & $25 \%$ & MEDIAN & $75 \%$ & $90 \%$ \\
\hline Wives & & & & \\
$\quad$ Minutes of paid work & 0 & 0 & 0 & 340 & 470 \\
Minutes of domestic work & 120 & 200 & 320 & 430 & 520 \\
Minutes of childcare & 0 & 10 & 80 & 180 & 280 \\
Husbands & & & & 530 & 590 \\
Minutes of paid work & 0 & 370 & 480 & 60 & 120 \\
Minutes of domestic work & 0 & 0 & 10 & 60 & 110 \\
Minutes of childcare & 0 & 0 & 10 & 1 & 1 \\
Shares of husbands time on total couple's time in the activity & & 0.185 & 0.364 \\
Minutes of paid work & 0.490 & 0.569 & 1 & 0.375 & 0.650 \\
Minutes of domestic work & 0 & 0 & 0.044 & 0.143 & \\
Minutes of childcare & 0 & 0 & & & \\
\hline
\end{tabular}

than men (320 vs. $40 \mathrm{~min}$ ) and three times more to childcare (112 min a day vs. $40 \mathrm{~min}$ for men). These figures are slightly less unbalanced for unpaid home production on weekends, with men spending (on average) almost twice as much time on household chores on weekends than on weekdays. However, mean statistics are not very informative on the distribution of time allocation, as they are very sensitive to extreme values.

Table 3 provides more detailed statistics on the distribution of the time allocated by husbands and wives to paid work, housework, and childcare, respectively, for weekday diaries, including the share of the husband in the total time allocated to each activity by the couple. Italian fathers spend, on average, about $40 \mathrm{~min}$ a day on housework and the same amount of time caring for their children (see Table 2) but the median values - which are representative of typical behavior and not driven, like the mean, by extreme values of the distribution-are much lower, and equal to $10 \mathrm{~min}$ each. Furthermore, more than a quarter of the married men in the sample did not perform any housework or childcare, while over $50 \%$ of the women did not perform any paid work. These findings are corroborated by the observation that men's share in paid work is $100 \%$ at the median (Table 3). However, on weekdays at least ten per cent of Italian married men spend at least $2 \mathrm{~h}$ on household chores and almost the same time on childcare on the day the diary was collected (see the statistics for men at the $90 \%$ deciles in Table 3).

Amazingly, husbands' median share of the total housework carried out by the couple during a weekday is less than $5 \%$ ! In contrast, their share of total childcare time at the couple level is $14 \%$.

This really sets Italian husbands at the bottom of the distribution of European men as far as their contribution to unpaid household work is concerned (see also Table 1), confirming the conclusions of earlier studies that time allocation is particularly unbalanced between Italian spouses, with men specializing in market work and women in household chores and childcare. 


\section{Results of estimation}

The econometric model specified in this paper allows for three different time usespaid work, childcare and household work-for the two spouses within each household. The remaining time use includes personal care, leisure and sleep. The model allows for corner solutions and the correlations across the errors of the equations are left unrestricted (see Sect. 2). We run the estimation separately for weekdays and weekend diaries. Table 4 presents the results of estimation for couples that completed the diary during a weekday. Table 5 presents similar results for weekend diaries. Correlations in unobservables across the system of six equations (three for each spouse) are estimated simultaneously (Tables 6, 7, respectively, for weekdays and weekends).

\subsection{Results of the models including week-days or weekend diaries}

We find hardly any effect of age. Even when dropping the spouse's age variables, own age remains insignificant.

Education plays a more important role. In particular, we find that men with only primary schooling (5 years of education) spend significantly less time on childcare activities than those who have completed 8 years of schooling (compulsory schooling, which is the reference category) on weekdays. Interestingly, the coefficient of this variable is still negative but statistically insignificant for weekends. The contrary is true for more highly educated fathers who spend significantly more time caring for their children on weekends. The coefficients of secondary and university education are positive, but statistically insignificant, for weekdays diaries. Men with only primary education work less on weekends (significant at ten per cent level) but no effect is found for weekdays.

In the case of women, those with higher levels of education spend significantly more time on paid work and childcare activities, while they perform significantly fewer household chores. This holds true at any time, even on weekends.

The number of children only affects the father's childcare load on weekends, but it has a much stronger effect for mothers: it reduces their labor market hours and increases their housework and childcare activities on any day of the week, although it does not affect their weekend hours of market work. The presence of young children reduces women's market hours and time dedicated to housework, while it strongly increases their childcare time. Childcare activities of husbands also increase significantly with the presence of children under six. This effect is strongly significant both on weekdays and weekends. However, the presence of small children under three only increases the time men devote to household chores on weekends, suggesting some scope for substitution between male and female home production over different weekdays.

Interestingly, men married to women with secondary education spend more time caring for their children and this effect is significant on weekends as well as on weekdays. If the wife has a university degree, this coefficient is positive, but not significant at conventional levels. The age of the spouse also has a significant 
Table 4 Results of estimation, weekdays diaries

\begin{tabular}{|c|c|c|c|c|}
\hline & \multicolumn{2}{|l|}{ Husbands } & \multicolumn{2}{|l|}{ Wives } \\
\hline & Coefficient & (Standard error) & Coefficient & (Standard error) \\
\hline \multicolumn{5}{|l|}{ Paid work time } \\
\hline Constant & 5.75 & (3.64) & $-13.68^{*}$ & (7.77) \\
\hline Age & -0.02 & $(0.24)$ & 0.44 & $(0.46)$ \\
\hline Age squared & -0.05 & $(0.27)$ & -0.43 & $(0.60)$ \\
\hline Primary ed. or less & 0.10 & $(0.42)$ & $-4.41 * *$ & $(1.17)$ \\
\hline Secondary education & 0.42 & $(0.30)$ & $2.37 * *$ & $(0.57)$ \\
\hline University degree & 0.06 & $(0.66)$ & $3.51^{* *}$ & $(1.12)$ \\
\hline Spouse's age & 0.07 & $(0.22)$ & 0.08 & $(0.50)$ \\
\hline Spouse's age squared & 0.00 & $(0.28)$ & -0.07 & $(0.59)$ \\
\hline Spouse's primary ed. or less & -0.42 & $(0.44)$ & -0.75 & $(0.97)$ \\
\hline Spouse's secondary ed. & 0.05 & $(0.28)$ & 0.19 & $(0.53)$ \\
\hline Spouse's University degree & 0.27 & $(0.73)$ & 0.51 & $(1.00)$ \\
\hline Number of children & 0.00 & $(0.17)$ & $-0.60^{*}$ & $(0.36)$ \\
\hline Youngest child $0-2$ years & 0.41 & $(0.38)$ & $-1.37 * *$ & $(0.68)$ \\
\hline Youngest child 3-5 years & 0.34 & $(0.41)$ & 0.09 & $(0.68)$ \\
\hline North & 0.28 & $(0.25)$ & $1.58^{* *}$ & $(0.47)$ \\
\hline \multicolumn{5}{|l|}{ House work time } \\
\hline Constant & -1.94 & $(1.78)$ & $8.87 * *$ & $(2.81)$ \\
\hline Age & -0.01 & $(0.11)$ & -0.06 & $(0.16)$ \\
\hline Age squared & 0.01 & $(0.13)$ & 0.08 & $(0.21)$ \\
\hline Primary ed. or less & -0.27 & $(0.21)$ & 0.35 & $(0.34)$ \\
\hline Secondary education & $0.28 * *$ & $(0.13)$ & $-0.92 * *$ & $(0.19)$ \\
\hline University degree & 0.08 & $(0.25)$ & $-1.79 * *$ & $(0.35)$ \\
\hline Spouse's age & 0.09 & $(0.11)$ & -0.14 & $(0.18)$ \\
\hline Spouse's age squared & -0.08 & $(0.14)$ & 0.22 & $(0.21)$ \\
\hline Spouse's primary ed. or less & -0.33 & $(0.21)$ & -0.25 & $(0.31)$ \\
\hline Spouse's secondary ed. & 0.09 & $(0.13)$ & -0.11 & $(0.18)$ \\
\hline Spouse's University degree & 0.27 & $(0.27)$ & $-0.54 *$ & $(0.33)$ \\
\hline Number of children & -0.05 & $(0.08)$ & $0.28 * *$ & $(0.13)$ \\
\hline Youngest child $0-2$ years & 0.19 & $(0.17)$ & -0.34 & $(0.26)$ \\
\hline Youngest child $3-5$ years & 0.09 & $(0.17)$ & -0.12 & $(0.26)$ \\
\hline North & $0.23 * *$ & $(0.11)$ & $-0.81 * *$ & $(0.16)$ \\
\hline \multicolumn{5}{|l|}{ Childcare time } \\
\hline Constant & $-3.81 *$ & 2.01 & 0.47 & $(1.72)$ \\
\hline Age & 0.10 & 0.12 & 0.01 & $(0.11)$ \\
\hline Age squared & -0.15 & 0.14 & -0.09 & $(0.15)$ \\
\hline Primary ed. or less & $-0.76^{* *}$ & 0.31 & 0.25 & $(0.25)$ \\
\hline Secondary education & 0.16 & 0.13 & $0.29 *$ & $(0.16)$ \\
\hline University degree & 0.23 & 0.26 & $0.73 * *$ & $(0.26)$ \\
\hline Spouse's age & 0.09 & 0.11 & 0.05 & $(0.11)$ \\
\hline
\end{tabular}


Table 4 continued

\begin{tabular}{llllll}
\hline & \multicolumn{2}{l}{ Husbands } & & \multicolumn{2}{l}{ Wives } \\
\cline { 2 - 3 } \cline { 5 - 6 } & Coefficient & (Standard error) & & Coefficient & (Standard error) \\
\hline Spouse's age squared & -0.15 & 0.15 & & -0.10 & $(0.14)$ \\
Spouse's primary ed. or less & 0.34 & 0.28 & -0.13 & $(0.27)$ \\
Spouse's secondary ed. & $0.33^{* *}$ & 0.13 & 0.18 & $(0.15)$ \\
Spouse's University degree & $0.42^{*}$ & 0.26 & & 0.41 & $(0.29)$ \\
Number of children & 0.12 & 0.09 & & $0.42^{* *}$ & $(0.09)$ \\
Youngest child 0-2 years & $1.17^{* *}$ & 0.17 & & $2.26^{* *}$ & 0.19 \\
Youngest child 3-5 years & $0.84^{* *}$ & 0.18 & & $1.17^{* *}$ & 0.20 \\
North & $0.14 * *$ & 0.12 & 0.04 & 0.13 \\
\hline
\end{tabular}

Correlations of unobservables of the six equations are shown in Table 5

* Significance at the $10 \%$ statistical significance level; ** Significance at the $5 \%$ level

non-linear impact on the husband's childcare time on weekends-it increases with her age but at a decreasing rate.

The husband's characteristics hardly have any effect on women's time allocation, the exception being men with a university degree. In this case we see a reduction of the wife's household chores on weekdays and her market work on weekends (both significant only at the ten per cent level).

Men residing in the North carry out significantly more housework and childcare than men living in other parts of the country and this is true both for weekends and weekdays. Residence in the North negatively affects the time men devote to paid work on weekends. For women, this effect is positive, but more strongly significant for weekdays than for weekends. Residing in the North significantly reduces the amount of housework carried out by women, everything else being equal, while it has no impact on women's childcare time.

\subsection{Effects of the unobservables}

Most estimated correlation coefficients between the unobservables of the six equations are statistically significant for both weekday and weekend models, as can be seen in Tables 6 and 7. For the interpretation of the correlation coefficients, it is important to be aware that they do not represent total correlations between time uses, but the residual correlations that cannot be explained by the variables included in the time allocation equations. Thus, they may capture not only unobserved individual preferences but also omitted variables, such as prices or non-labor income that were not available in the dataset.

The unobservables of the equations explaining the time allocated by each parent to household chores and childcare are strongly negatively correlated with the unobservables of the equations for own paid work. This indicates that the unobservable factors that increase market hours reduce non-market time. For instance, individuals who have preferences for market work will have preferences for performing less childcare and fewer household chores. 
Table 5 Results of estimation, weekend days diaries only

\begin{tabular}{|c|c|c|c|c|}
\hline & \multicolumn{2}{|l|}{ Husbands } & \multicolumn{2}{|l|}{ Wives } \\
\hline & Coefficient & (Standard error) & Coefficient & (Standard error) \\
\hline \multicolumn{5}{|l|}{ Paid work time } \\
\hline Constant & $14.45^{*}$ & $(7.84)$ & -5.56 & (14.39) \\
\hline Age & -0.38 & $(0.46)$ & -0.98 & $(0.78)$ \\
\hline Age squared & 0.48 & $(0.54)$ & 1.21 & $(0.97)$ \\
\hline Primary ed. or less & $-1.62 *$ & $(0.87)$ & -2.30 & $(1.85)$ \\
\hline Secondary education & $-1.53^{* *}$ & $(0.54)$ & $2.54 * *$ & $(0.88)$ \\
\hline University degree & 0.18 & $(1.02)$ & $4.48 * *$ & $(2.00)$ \\
\hline Spouse's age & -0.50 & $(0.45)$ & 0.57 & $(0.86)$ \\
\hline Spouse's age squared & 0.64 & $(0.57)$ & -0.47 & $(1.00)$ \\
\hline Spouse's primary ed. or less & -0.31 & $(0.99)$ & -0.69 & $(1.47)$ \\
\hline Spouse's secondary ed. & 0.03 & $(0.53)$ & -1.16 & $(0.84)$ \\
\hline Spouse's University degree & $-2.14 *$ & $(1.09)$ & $-3.03 *$ & $(1.80)$ \\
\hline Number of children & $0.59^{*}$ & $(0.36)$ & -0.92 & $(0.65)$ \\
\hline Youngest child $0-2$ years & -0.37 & $(0.78)$ & $-2.66^{*}$ & $(1.36)$ \\
\hline Youngest child $3-5$ years & 0.17 & $(0.69)$ & -1.02 & $(1.11)$ \\
\hline North & $-2.00 * *$ & $(0.51)$ & $1.42 *$ & $(0.77)$ \\
\hline \multicolumn{5}{|l|}{ Housework time } \\
\hline Constant & -2.28 & $(1.86)$ & $6.28 * *$ & $(2.15)$ \\
\hline Age & 0.02 & $(0.11)$ & -0.10 & $(0.13)$ \\
\hline Age squared & -0.02 & $(0.13)$ & 0.16 & $(0.16)$ \\
\hline Primary ed. or less & $0.38 * *$ & $(0.17)$ & 0.28 & $(0.25)$ \\
\hline Secondary education & $0.26 * *$ & $(0.12)$ & $-0.32 * *$ & $(0.14)$ \\
\hline University degree & 0.32 & $(0.21)$ & $-1.08 * *$ & $(0.27)$ \\
\hline Spouse's age & 0.08 & $(0.10)$ & -0.03 & $(0.13)$ \\
\hline Spouse's age squared & -0.06 & $(0.13)$ & 0.06 & $(0.15)$ \\
\hline Spouse's primary ed. or less & 0.07 & $(0.21)$ & 0.38 & $(0.24)$ \\
\hline Spouse's secondary ed. & $0.22 *$ & $(0.12)$ & -0.12 & $(0.14)$ \\
\hline Spouse's University degree & 0.27 & $(0.22)$ & -0.41 & $(0.27)$ \\
\hline Number of children & 0.04 & $(0.08)$ & $0.57 * *$ & $(0.10)$ \\
\hline Youngest child $0-2$ years & $0.45 * *$ & $(0.17)$ & $-0.51 * *$ & $(0.22)$ \\
\hline Youngest child $3-5$ years & 0.03 & $(0.15)$ & $-0.37 * *$ & $(0.19)$ \\
\hline North & $0.59 * *$ & $(0.10)$ & $-0.61 * *$ & $(0.12)$ \\
\hline \multicolumn{5}{|l|}{ Childcare time } \\
\hline Constant & $-5.81 * *$ & $(1.94)$ & -1.17 & $(1.60)$ \\
\hline Age & -0.07 & $(0.12)$ & 0.12 & $(0.09)$ \\
\hline Age squared & 0.01 & $(0.14)$ & $-0.21 *$ & $(0.12)$ \\
\hline Primary ed. or less & -0.24 & $(0.24)$ & -0.35 & $(0.22)$ \\
\hline Secondary education & $0.26 * *$ & $(0.13)$ & $0.30 * *$ & $(0.10)$ \\
\hline University degree & $0.91 * *$ & $(0.24)$ & $0.58 * *$ & $(0.19)$ \\
\hline Spouse's age & $0.36 * *$ & $(0.12)$ & $-0.02 * *$ & $(0.09)$ \\
\hline
\end{tabular}


Table 5 continued

\begin{tabular}{llllll}
\hline & \multicolumn{3}{l}{ Husbands } & & \multicolumn{2}{l}{ Wives } \\
\cline { 2 - 3 } \cline { 5 - 6 } & Coefficient & (Standard error) & & Coefficient & (Standard error) \\
\hline Spouse's age squared & $-0.45^{* *}$ & $(0.16)$ & & $0.00^{* *}$ & $(0.11)$ \\
Spouse's primary ed. or less & -0.14 & $(0.28)$ & 0.14 & $(0.19)$ \\
Spouse's secondary ed. & $0.41^{* *}$ & $(0.13)$ & & 0.01 & $(0.10)$ \\
Spouse's University degree & 0.22 & $(0.28)$ & & 0.26 & $(0.18)$ \\
Number of children & $0.21^{* *}$ & $(0.09)$ & & $0.31^{* *}$ & $(0.07)$ \\
Youngest child 0-2 years & $1.74 * *$ & $(0.17)$ & & $2.50^{* *}$ & $(0.14)$ \\
Youngest child 3-5 years & $1.01^{* *}$ & $(0.16)$ & & $1.29 * *$ & $(0.13)$ \\
North & $0.29 * *$ & $(0.11)$ & 0.08 & $(0.09)$ \\
\hline
\end{tabular}

Correlations of unobservables of the six equations are shown in Table 7

* Significance at the $10 \%$ statistical significance level; ** Significance at the $5 \%$ level

Table 6 Covariance matrix errors for the model of weekday diaries: standard deviations on main diagonal, correlation coefficients off-diagonal

\begin{tabular}{lcccccc}
\hline & $\begin{array}{l}\text { Paid work } \\
\text { husband }\end{array}$ & $\begin{array}{l}\text { Housework } \\
\text { husband }\end{array}$ & $\begin{array}{l}\text { Childcare } \\
\text { husband }\end{array}$ & $\begin{array}{l}\text { Paid work } \\
\text { wife }\end{array}$ & $\begin{array}{l}\text { Housework } \\
\text { wife }\end{array}$ & $\begin{array}{l}\text { Childcare } \\
\text { wife }\end{array}$ \\
\hline Paid work husband & $3.49^{* *}$ & & & & & \\
Housework husband & $-0.41^{* *}$ & $1.46^{* *}$ & & & & \\
Childcare husband & $-0.24 * *$ & $0.20^{* *}$ & $1.47^{* *}$ & & & \\
Paid work wife & $0.13^{* *}$ & $0.17^{* *}$ & $0.08^{*}$ & $5.98^{* *}$ & \\
Housework wife & $0.07^{* *}$ & $-0.13^{* *}$ & $-0.10^{* *}$ & $-0.74^{* *}$ & $2.32^{* *}$ & $1.70^{* *}$ \\
Childcare wife & $0.10^{* *}$ & $-0.07^{*}$ & $0.26^{* *}$ & $-0.26^{* *}$ & 0.06 & 06 \\
\hline
\end{tabular}

* Significance at the $10 \%$ statistical significance level; ** Significance at the $5 \%$ level

The unobservables of the equation explaining paid work of the two parents are strongly positively correlated, even after correcting for age and education. This suggests positive assortative mating-individuals marry others who have similar (unobserved) preferences for market work. The same finding applies to the unobservables of childcare time performed by the two parents, indicating that individuals marry others who have similar tastes for childcare.

While the unobservables of paid work and childcare of the partners are positively correlated, the same is not true for household chores. The unobservable factors influencing time dedicated by the spouses to housework are positively correlated on weekends and negatively so on weekdays. This highlights the scope for substitution between the husband's and the wife's time inputs into the production of household chores on weekdays, while complementarities show up on weekends, when parents likely have more time available for household production. Furthermore, the unobservable of the equation for paid work of one partner is positively correlated with the unobservables determining the childcare and household chores time of the 
Table 7 Covariance matrix errors for the model including only weekend days: standard deviations on main diagonal, correlation coefficients off-diagonal

\begin{tabular}{lccllll}
\hline & $\begin{array}{l}\text { Paid work } \\
\text { husband }\end{array}$ & $\begin{array}{l}\text { Housework } \\
\text { husband }\end{array}$ & $\begin{array}{l}\text { Childcare } \\
\text { husband }\end{array}$ & $\begin{array}{l}\text { Paid work } \\
\text { wife }\end{array}$ & $\begin{array}{l}\text { Housework } \\
\text { wife }\end{array}$ & $\begin{array}{l}\text { Childcare } \\
\text { wife }\end{array}$ \\
\hline Paid work husband & $7.83^{* *}$ & & & & & \\
Housework husband & $-0.30^{* *}$ & $1.87^{* *}$ & & & & \\
Childcare husband & $-0.19^{* *}$ & $0.17^{* *}$ & $1.96^{* *}$ & & & \\
Paid work wife & $0.31^{* *}$ & 0.06 & $0.08^{*}$ & $8.86^{* *}$ & & \\
Housework wife & $0.20^{* *}$ & $0.19^{* *}$ & 0.02 & $-0.35^{* *}$ & $2.42^{* *}$ & \\
Childcare wife & $0.16^{* *}$ & -0.01 & $0.31^{* *}$ & $-0.13^{* *}$ & -0.01 & $1.68^{* *}$ \\
\hline
\end{tabular}

* Significance at the $10 \%$ statistical significance level; ** Significance at the $5 \%$ level

other. This implies that if one spouse has stronger preferences for market work, the other tends to prefer home production. These findings-suggestive of specialization-are stronger for the correlations in the errors of paid work of men and unpaid tasks of women, possibly suggesting that men "pay" for women's work in chores and childcare (Grossbard-Schechtman 1984; Grossbard-Shechtman 2003).

\subsection{Results of the models including own and cross-wage rates}

We have also estimated a variant of the model including the predicted wage rates of the two spouses among the covariates. Predicted wages are drawn from the 2002 Bank of Italy SHIW dataset (see Sect. 2 for more econometric details and Sect. 3.3 for an account of the imputation procedure). The results are shown in Table 8, which gives the estimated coefficients on his and her wage rate, respectively, for the model of weekday diaries and that of weekend diaries. The coefficients on the other covariates are not shown. ${ }^{21}$ As mentioned earlier, economic theory does not unequivocally predict the signs of the wage elasticities of spousal non-market time. For the weekday estimation, most of the wage effects are statistically insignificant, with the exception of the coefficient on the wage rate of the wife in the equation explaining men's time allocated to household chores. This finding confirms earlier conclusions in the literature for France that men's home production is responsive to the wage of the wife: the higher her wage rate, the more household chores he performs or, vice versa that the husband's greater involvement in housework allows his wife to earn a higher wage (Bloemen and Stancanelli 2008).

In contrast, US studies have shown that there is hardly any effect of wages on spousal time allocation (Kalenkoski et al. 2009; Kimmel and Connelly 2007). However, Bloemen and Stancanelli (2008) argue that earlier insignificant findings for the effects of wages might be due to misspecification of the model (not allowing for simultaneity of parental choices and ignoring endogeneity of wages) or to data shortcomings such as lack of information on actual time use of the spouse.

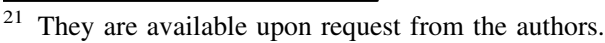


Table 8 Own and cross wage effects on time allocation

\begin{tabular}{lcccc}
\hline & $\begin{array}{l}\text { Coefficient on } \\
\text { husband's wage }\end{array}$ & $\begin{array}{l}\text { (Standard } \\
\text { error) }\end{array}$ & $\begin{array}{l}\text { Coefficient } \\
\text { on wife's wage }\end{array}$ & $\begin{array}{l}\text { (Standard } \\
\text { error) }\end{array}$ \\
\hline $\begin{array}{l}\text { Weekdays (model of Table 5) } \\
\text { Paid work husband }\end{array}$ & 0.18 & $(0.44)$ & 0.15 & $(0.16)$ \\
Paid work wife & 0.40 & $(0.25)$ & -0.47 & $(2.67)$ \\
Housework husband & -0.14 & $(0.20)$ & $0.14 * *$ & $(0.07)$ \\
Housework wife & -0.13 & $(0.09)$ & 0.001 & $(0.74)$ \\
Childcare husband & 0.35 & $(0.22)$ & 0.08 & $(0.07)$ \\
Childcare wife & 0.08 & $(0.07)$ & -0.10 & $(0.24)$ \\
Weekend days only (model of & Table 8$)$ & $(0.72)$ & -0.31 & $(0.28)$ \\
Paid work husband & $-1.59^{* *}$ & $(0.41)$ & 1.68 & $(1.16)$ \\
Paid work wife & -0.61 & $(0.16)$ & $0.13 * *$ & $(0.06)$ \\
Housework husband & $0.33^{* *}$ & $(0.41)$ & 0.007 & $(0.21)$ \\
Housework wife & -0.07 & $(0.18)$ & 0.11 & $(0.07)$ \\
Childcare husband & $0.43^{* *}$ & $(0.05)$ & 0.23 & $(0.16)$ \\
Childcare wife & 0.01 & & & \\
\hline
\end{tabular}

Wages are predicted using wage regressions from the Bank of Italy 2002 household sample. The other covariates are the same as in the models of Tables 5 and 8, respectively. Coefficients are not shown. The correlations of the unobservables of the six equations are not shown either

The standard errors are corrected by bootstrapping

* Significance at the $10 \%$ statistical significance level; ** Significance at the $5 \%$ level

For the weekend estimation, we found some significant effects: husband's wage increases (decreases) the time he devotes to housework and childcare (paid work). This may reflect a backward bending labor supply, with individuals disliking work on weekends, or the fact that low paid jobs require work on weekends more often than highly paid jobs do. On weekends wife's wage increases the housework time of her husband.

\subsection{Pooling weekends and weekdays}

We have estimated the main model for the full sample, pooling together observations for weekdays and weekends. The results of this estimation are given in the "Appendix" Tables 10 and 12.

The variables that affected the spouses' allocation of time in the same direction for either weekday or weekend day diaries (see Tables 4, 5) are estimated more precisely, as expected, while the findings are more mixed for covariates that affected the allocation of time on weekends and weekdays in opposite direction. For instance, in the pooled model, men residing in the North appear significantly less likely to work in the market (see Table 10), while we know that it is the weekend days that drive the significant coefficient. This variable was not found to be significant for weekdays (see Table 4) but only on weekends (see Table 5). Since 
the sample for weekend days is twice as large as that for weekdays, by construction (see Sect. 3), the effect for weekend days overrides that for weekdays diaries.

The weekend dummy positively affects the time devoted by husbands to household chores but negatively affects that allocated to childcare by women.

\section{Conclusions}

In this paper, we study simultaneously spouses' time allocation decisions regarding market work and non-market time, distinguishing three time uses: paid work, childcare and housework.

We find that educational level, the number of children, and the age of the youngest child affect time allocation, these patterns differ substantially across weekdays and weekends. Men with only primary schooling spend significantly less time on childcare activities during weekdays, while more highly educated fathers spend significantly more time caring for their children during weekends. On the other hand, more highly educated women spend significantly more time on paid work and childcare activities, but they perform significantly fewer household chores than women with only compulsory education on any day of the week or weekend.

While the number of children only affects the fathers' childcare time on weekends, it is more often significant for the mothers, reducing their labor market hours and increasing their housework and childcare activities on any day of the week. Furthermore, the presence of young children reduces market hours and housework time of women, while it strongly increases their childcare time. Also, childcare provided by husbands increases significantly with the presence of young children, and this effect is strongly significant both for weekdays and weekends. The presence of very young children, under three, positively affects the time men devote to household chores on weekends.

Interestingly, men married to women with secondary education spend more time caring for their children. This effect is significant in both models. The husband's characteristics hardly have any effect on women's time allocation with the exception husband's university degree, which significantly reduces her market work on weekends and her household chores on weekdays.

Residing in the north increases the amount of housework and childcare done by fathers and reduces housework produced by women, while it has no impact on women's childcare.

Most estimated correlation coefficients are statistically significant. The errors between the equations for housework of the two parents suggest complementarities between the husband and wife's time inputs into the household production on weekends, but substitutability on the other days of the week. The unobservables determining the time devoted to childcare and household chores by one spouse are positively correlated with those of paid work of the other spouse, indicating specialization.

We can therefore conclude that, even if a traditional division of domestic and childcare tasks still prevails among Italian spouses, paid and unpaid work are 
slightly more balanced between more highly educated spouses when the wife is working. While confirming earlier conclusions in the literature that Italian mothers' time allocation is very sensitive to the presence of young children, we find that fathers' childcare time also increases significantly when there are young children in the household.

Acknowledgments The analysis carried out in the paper is part of a research project on the economics of couples that has been financed by the French National Research Agency (ANR). We are grateful to the ANR for financial support. The Italian data were made available by CHILD-CCA. Earlier versions of this paper were presented at the annual conference of the European Society for Population Economics, in Sevilla, in June 2009. We thank Dan Hamermesh, Shoshana Grossbard, Leslie Stratton, and two anonymous referees for their helpful advice. We bear responsibility for any errors.

Open Access This article is distributed under the terms of the Creative Commons Attribution Noncommercial License which permits any noncommercial use, distribution, and reproduction in any medium, provided the original author(s) and source are credited.

\section{Appendix}

See Tables 9, 10, 11, and 12 .

Table 9 Sample descriptive statistics, weekend days-Italian Time Use Survey, 2002-2003 (SD in brackets)

\begin{tabular}{lcc}
\hline & Husbands & \multicolumn{1}{l}{ Wives } \\
\hline Age & $41.6(6.77)$ & $38.1(6.48)$ \\
Primary education & $0.09(0.29)$ & $0.07(0.26)$ \\
Compulsory education (excluded) & $0.42(0.49)$ & $0.42(0.49)$ \\
Secondary education & $0.51(0.50)$ & $0.51(0.50)$ \\
University degree & $0.08(0.27)$ & $0.08(0.26)$ \\
Employed & $0.96(0.20)$ & $0.48(0.50)$ \\
Potential work experience & $25.24(7.45)$ & $21.63(7.25)$ \\
Hourly wage, Euros & $7.61(1.21)$ & $6.60(1.09)$ \\
Paid work time (minutes) & $122.5(199.3)$ & $37.7(115.5)$ \\
Housework (minutes) & $71.6(87.1)$ & $81.3(100.7)$ \\
Childcare time (minutes) & $48.3(77.6)$ & \\
\hline & Household characteristics & \\
\hline Children number & $1.64(0.67)$ & \\
Youngest child aged 0-2 & $0.21(0.41)$ & \\
Youngest child aged 3-5 & $0.19(0.39)$ & \\
North & $0.40(0.49)$ & \\
Regional unemployment rate & $10.4(7.34)$ & \\
N. obs. & 1,784 & \\
\hline
\end{tabular}

Note: see data section for more information on the variables in this table 
Table 10 Results of estimation, week and weekend days diaries

\begin{tabular}{|c|c|c|c|c|}
\hline & \multicolumn{2}{|l|}{ Husbands } & \multicolumn{2}{|l|}{ Wives } \\
\hline & Coefficient & (Standard error) & Coefficient & (Standard error) \\
\hline \multicolumn{5}{|l|}{ Paid work time } \\
\hline Constant & $13.24 * *$ & $(3.59)$ & -6.71 & $(6.56)$ \\
\hline Age & -0.16 & $(0.22)$ & -0.10 & $(0.37)$ \\
\hline Age squared & 0.16 & $(0.26)$ & 0.18 & $(0.47)$ \\
\hline Primary ed. or less & $-0.72 *$ & $(0.41)$ & $-3.43 * *$ & $(0.90)$ \\
\hline Secondary education & -0.43 & $(0.27)$ & $2.25 * *$ & $(0.44)$ \\
\hline University degree & 0.04 & $(0.52)$ & $3.33 * *$ & $(0.93)$ \\
\hline Spouse's age & -0.17 & $(0.21)$ & 0.22 & $(0.40)$ \\
\hline Spouse's age squared & 0.26 & $(0.27)$ & -0.17 & $(0.47)$ \\
\hline Spouse's primary ed. or less & -0.36 & $(0.46)$ & -0.62 & $(0.76)$ \\
\hline Spouse's secondary ed. & 0.09 & $(0.27)$ & -0.38 & $(0.41)$ \\
\hline Spouse's University degree & -0.73 & $(0.56)$ & -0.57 & $(0.83)$ \\
\hline Number of children & 0.22 & $(0.17)$ & $-0.83 * *$ & $(0.30)$ \\
\hline Youngest child $0-2$ years & 0.12 & $(0.38)$ & $-1.57 * *$ & $(0.59)$ \\
\hline Youngest child 3-5 years & 0.29 & $(0.35)$ & -0.17 & $(0.55)$ \\
\hline North & $-0.74 * *$ & $(0.24)$ & $1.27 * *$ & $(0.38)$ \\
\hline Weekend diary dummy & $-7.84 * *$ & $(0.38)$ & $-5.89 * *$ & $(0.54)$ \\
\hline \multicolumn{5}{|l|}{ Housework time } \\
\hline Constant & $-2.80 * *$ & $(1.30)$ & $7.41 * *$ & $(1.65)$ \\
\hline Age & 0.03 & $(0.08)$ & -0.07 & $(0.09)$ \\
\hline Age squared & -0.03 & $(0.09)$ & 0.12 & $(0.12)$ \\
\hline Primary ed. or less & 0.16 & $(0.13)$ & 0.30 & $(0.20)$ \\
\hline Secondary education & $0.26 * *$ & $(0.09)$ & $-0.54 * *$ & $(0.11)$ \\
\hline University degree & 0.24 & $(0.16)$ & $-1.33 * *$ & $(0.21)$ \\
\hline Spouse's age & 0.07 & $(0.07)$ & -0.08 & $(0.10)$ \\
\hline Spouse's age squared & -0.05 & $(0.09)$ & 0.13 & $(0.12)$ \\
\hline Spouse's primary ed. or less & -0.08 & $(0.15)$ & 0.11 & $(0.19)$ \\
\hline Spouse's secondary ed. & $0.18 * *$ & $(0.09)$ & -0.13 & $(0.11)$ \\
\hline Spouse's University degree & 0.27 & $(0.17)$ & $-0.45 * *$ & $(0.21)$ \\
\hline Number of children & 0.00 & $(0.06)$ & $0.47 * *$ & $(0.07)$ \\
\hline Youngest child $0-2$ years & $0.36^{* *}$ & $(0.12)$ & $-0.48 * *$ & $(0.17)$ \\
\hline Youngest child 3-5 years & 0.06 & $(0.11)$ & $-0.27 *$ & $(0.15)$ \\
\hline North & $0.45 * *$ & $(0.07)$ & $-0.67 * *$ & $(0.10)$ \\
\hline Weekend diary dummy & $0.69 * *$ & $(0.08)$ & -0.16 & $(0.10)$ \\
\hline \multicolumn{5}{|l|}{ Childcare time } \\
\hline Constant & $-4.96 * *$ & $(1.36$ & -0.01 & $(1.13)$ \\
\hline Age & 0.01 & $(0.08$ & 0.08 & $(0.07)$ \\
\hline Age squared & -0.07 & $(0.10$ & $-0.17 *$ & $(0.09)$ \\
\hline Primary ed. or less & $-0.45 * *$ & $(0.17$ & -0.10 & $(0.16)$ \\
\hline Secondary education & $0.22 * *$ & $(0.09$ & $0.29 * *$ & $(0.08)$ \\
\hline
\end{tabular}


Table 10 continued

\begin{tabular}{|c|c|c|c|c|}
\hline & \multicolumn{2}{|l|}{ Husbands } & \multicolumn{2}{|l|}{ Wives } \\
\hline & Coefficient & (Standard error) & Coefficient & (Standard error) \\
\hline \multicolumn{5}{|c|}{ Results of estimation week and weekend days diaries } \\
\hline University degree & $0.69 * *$ & $(0.17)$ & $0.64 * *$ & $(0.15)$ \\
\hline Spouse's age & $0.23 * *$ & $(0.08)$ & 0.00 & $(0.07)$ \\
\hline Spouse's age squared & $-0.31 * *$ & $(0.11)$ & -0.03 & $(0.08)$ \\
\hline Spouse's primary ed. or less & 0.08 & $(0.20)$ & 0.03 & $(0.15)$ \\
\hline Spouse's secondary ed. & $0.38 * *$ & $(0.09)$ & 0.06 & $(0.08)$ \\
\hline Spouse's University degree & 0.29 & $(0.19)$ & $0.33 * *$ & $(0.15)$ \\
\hline Number of children & $0.17 * *$ & $(0.06)$ & $0.35 * *$ & $(0.06)$ \\
\hline Youngest child $0-2$ years & $1.52 * *$ & $(0.12)$ & $2.40 * *$ & $(0.11)$ \\
\hline Youngest child 3-5 years & $0.93 * *$ & $(0.12)$ & $1.25^{* *}$ & $(0.11)$ \\
\hline North & $0.23 * *$ & $(0.08)$ & 0.06 & $(0.07)$ \\
\hline Weekend diary dummy & 0.13 & $(0.09)$ & $-0.72 * *$ & $(0.07)$ \\
\hline
\end{tabular}

Correlations of unobservables of the six equations are shown in Table 11

* Significance at the $10 \%$ statistical significance level; ** Significance at the $5 \%$ level

Table 11 Covariance matrix errors for the model including week and weekend days: standard deviations on main diagonal, correlation coefficients off-diagonal

\begin{tabular}{lcccccc}
\hline & $\begin{array}{l}\text { Paid work } \\
\text { husband }\end{array}$ & $\begin{array}{l}\text { Housework } \\
\text { husband }\end{array}$ & $\begin{array}{l}\text { Childcare } \\
\text { husband }\end{array}$ & $\begin{array}{l}\text { Paid work } \\
\text { wife }\end{array}$ & $\begin{array}{l}\text { Housework } \\
\text { wife }\end{array}$ & $\begin{array}{l}\text { Childcare } \\
\text { wife }\end{array}$ \\
\hline Paid work husband & $5.37^{* *}$ & & & & & \\
Housework husband & $-0.33^{* *}$ & $1.75^{* *}$ & & & & \\
Childcare husband & $-0.22^{* *}$ & $0.18^{* *}$ & $1.79 * *$ & & & \\
Paid work wife & $0.26^{* *}$ & $0.08^{* *}$ & $0.06^{* *}$ & $6.92^{* *}$ & \\
Housework wife & $0.14^{* *}$ & $0.09^{* *}$ & -0.02 & $-0.54 * *$ & $2.40^{* *}$ & $1.69 * *$ \\
Childcare wife & $0.13^{* *}$ & -0.03 & $0.29 * *$ & $-0.19 * *$ & 0.02 & 1.02 \\
\hline
\end{tabular}

* Significance at the $10 \%$ statistical significance level; ** Significance at the $5 \%$ level

Table 12 Descriptive statistics of samples used for wage predictions-Survey of Household Income and Wealth (SHIW) and Italian Time Use (ITU)

\begin{tabular}{lll}
\hline (Mean values, SD in brackets) & SHIW & ITU \\
\hline Women & & \\
Hourly wages $\left(^{*}\right)$ & $7.62(5.78)$ & NA \\
Children number & $1.43(1.01)$ & $1.43(0.97)$ \\
Youngest child aged 0-2 & $0.07(0.25)$ & $0.08(0.27)$ \\
Youngest child aged 3-5 & $0.06(0.24)$ & $0.07(0.25)$ \\
Youngest child aged 6-13 & $0.17(0.37)$ & $0.17(0.37)$ \\
Youngest child aged 14-18 & $0.13(0.34)$ & $0.13(0.33)$ \\
Youngest child aged $>18$ & $0.37(0.48)$ & $0.38(0.48)$ \\
\hline
\end{tabular}


Table 12 continued

\begin{tabular}{|c|c|c|}
\hline (Mean values, SD in brackets) & SHIW & ITU \\
\hline Presence in the household of other adults older than 55 & $0.61(0.24)$ & $0.03(0.17)$ \\
\hline Unemployment rate & $9.83(7.20)$ & $9.57(7.09)$ \\
\hline Primary education or less & $0.18(0.38)$ & $0.14(0.35)$ \\
\hline Intermediary education & $0.33(0.47)$ & $0.32(0.47)$ \\
\hline Lower secondary school & $0.07(0.25)$ & $0.08(0.27)$ \\
\hline Upper secondary & $0.32(0.47)$ & $0.36(0.48)$ \\
\hline University short degree & $0.01(0.10)$ & $0.01(0.11)$ \\
\hline University standard degree & $0.09(0.29)$ & $0.08(0.27)$ \\
\hline Potential work experience (age minus years of education) & $24.70(12.57)$ & $22.58(13.56)$ \\
\hline Married & $0.69(0.46)$ & $0.62(0.48)$ \\
\hline N. obs. & 4,853 & 14,481 \\
\hline \multicolumn{3}{|l|}{ Men } \\
\hline Hourly wages $(*)$ & $7.99(5.06)$ & NA \\
\hline Children number & $1.51(1.03)$ & $1.42(0.97)$ \\
\hline Youngest child aged $0-2$ & $0.07(0.25)$ & $0.07(0.26)$ \\
\hline Youngest child aged $3-5$ & $0.06(0.23)$ & $0.62(0.24)$ \\
\hline Youngest child aged $6-13$ & $0.17(0.37)$ & $0.16(0.37)$ \\
\hline Youngest child aged $14-18$ & $0.13(0.34)$ & $0.13(0.33)$ \\
\hline Youngest child aged $>18$ & $0.39(0.49)$ & $0.39(0.49)$ \\
\hline Presence in the household of other adults older than 55 & $0.06(0.23)$ & $0.03(0.18)$ \\
\hline Unemployment rate & $9.92(7.27)$ & $9.33(6.97)$ \\
\hline Primary education or less & $0.11(0.31)$ & $0.11(0.31)$ \\
\hline Intermediary education & $0.37(0.48)$ & $0.36(0.48)$ \\
\hline Lower secondary school & $0.08(0.28)$ & $0.08(0.28)$ \\
\hline Upper secondary & $0.33(0.47)$ & $0.35(0.48)$ \\
\hline University short degree & $0.01(0.09)$ & $0.01(0.09)$ \\
\hline University standard degree & $0.09(0.28)$ & $0.08(0.27)$ \\
\hline Potential work experience (age minus years of education) & $22.20(12.06)$ & $22.13(13.3)$ \\
\hline Married & $0.57(0.49)$ & $0.56(0.50)$ \\
\hline N. obs. & 3,936 & 11,820 \\
\hline
\end{tabular}

Notice that the sample includes single people, as well as childless couples and couples with children of any age, to gather representative wage information, as here we do not expect employers to pay different wages according to family situation

* Mean hourly wages are reported only for individuals with positive wages (see Sect. 3.3 for details)

\section{References}

Amemiya, T. (1985). Advanced econometrics. Harvard: Harvard University Press.

Anxo, D., Flood, L., Mencarini, L., Pailhé, A., Solaz, A., \& Tanturri, M. L. (2007). Time allocation between work and family over the life-cycle: A comparative gender analysis of Italy, France, Sweden and US. IZA DP No. 3193.

Apps, P. F., \& Rees, R. (1997). Collective labor supply and household production. Journal of Political Economy, 105, 178-190. 
Apps, P., \& Rees, R. (2002). Household production,full consumption and the costs of children. Labour Economics, 8, 621-648.

Apps, P., \& Rees, R. (2009). Public economics and the household. Cambridge: Cambridge University Press.

Becker, G. S. (1965). A theory of the allocation of time. The Economic Journal, 75(299), 493-517.

Bloemen, H. G., \& Stancanelli, E. F. G. (2008). How do spouses allocate time: The impact of wages and income. IZA DP No. 3679, September.

Börsch-Supan, A., \& Hajivassiliou, V. (1993). Smooth unbiased multivariate probability simulators for maximum likelihood estimation of limited dependent variable models. Journal of Econometrics, 58(3), 347-368.

Burda, M., Hamermesh, D. S., \& Weil, P. (2006). The distribution of total work in the EU and US. IZA DP 2270.

Burda, M., Hamermesh, D. S., \& Weil, P. (2007). Total work, gender and social norms. NBER WP 13000

Chiappori, P.-A. (1997). Introducing household production in collective models of labour supply. Journal of Political Economy, 105(1), 191-209.

Connelly, R., \& Kimmel, J. (2009). Spousal influences on parents' non-market time choices. Review of Economics of the Household, 7(4), 361-394.

Del Boca, D., Pasqua, S., \& Pronzato, C. (2007). An empirical analysis of the effects of social policies on fertility, labour market participation and earnings of European women. In D. Del Boca \& C. Wetzels (Eds.), Social policies, labour markets and motherhood: A comparative analysis of European countries. Cambridge: Cambridge University Press.

Del Boca, D., Pasqua, S., \& Pronzato, C. (2009). Motherhood and market work decisions in institutional context: An European perspective. Oxford Economic Papers, 61(Special Issue), i147-i171.

Del Boca, D., \& Wetzels, C. (Eds.). (2007). Social policies, labour markets and motherhood: A comparative analysis of European countries. Cambridge: Cambridge University Press.

Gronau, R. (1977). Leisure, home production and work. The theory of the allocation of time revisited. Journal of Political Economy, 85(6), 1099-1124.

Grossbard-Schechtman, A. (1984). A theory of allocation of time in markets for labour and marriage. The Economic Journal, 94, 863-882.

Grossbard-Shechtman, S. (2003). A consumer theory with competitive markets for work in marriage. Journal of Socio-Economics, 31(6), 609-645.

Jepsen, L. K. (2005). The relationship between wife education and husband's earnings: Evidence from 1960 to 2000. Review of the Economics of the Household, 3, 197-214.

Kalenkoski, C. M., \& Foster, G. (2008). The quality of time spent with children in Australian households. Review of Economics of the Household, 6(3), 243-266.

Kalenkoski, C., Ribar, D., \& Stratton, L. (2009). The influence of wages on parents' time allocation of time to child care and market work in the United Kingdom. Journal of Population Economics, 22(2), 399-419.

Kimmel, J., \& Connelly, R. (2007). Mothers' time choices. Caregiving, leisure, home production, and paid work. The Journal of Human Resources, XLII(3), 643-681.

Kooreman, P., \& Kapteyn, A. (1987). A disaggregated analysis of the allocation of time within the household. The Journal of Political Economy, 95(2), 223-249.

Manser, M., \& Brown, M. (1980). Marriage and household decision-making: A bargaining analysis. International Economic Review, 1(6), 31-44.

McElroy, M. B., \& Horney, M. J. (1981). Nash-bargained household decisions: Towards a generalization of the theory of demand. International Economic Review, 22(2), 333-349.

Mencarini, L., \& Tanturri, M. L. (2004). Time use, family role-set and childbearing among Italian working women. Genus, $L X$, III.

Mincer, J. (1962). Labor force participation of married women: a study of labor supply. In H. G. Lewis (Ed.), Aspects of Labor Economics. Princeton, NJ: Princeton University Press for the National Bureau of Economic Research.

OECD. (2001). Employment outlook, "Balancing work and family life: Helping parents into paid employment", Chapter 4.

Olivetti, C., \& Petrongolo, B. (2008). Unequal pay or unequal employment? A cross-country analysis of gender gaps. The Journal of Labor Economics, 26(4), 621-654.

Song, Y. (2007). The working spouse penalty/premium and married women's labor supply. Review of the Economics of the Household, 5, 279-304. 